\title{
CAVES AND KARSTS OF NORTHEAST AFRICA
}

\author{
William R. HALLIDAY ${ }^{1}$
}

\begin{abstract}
At least potentially karstifiable rocks cover much of the surface of Egypt and northern Libya. Study of caves and other karstic features of this region has been hampered by lack of roads, rapid disintegration of the surface of friable, poorly consolidated limestone, wind-blown sand and other factors. Interbedding with marly aquicludes hampers speleogenesis locally. Calcareous and evaporite karsts are present, however, and their waters are important albeit generally limited resources. Large quantities of fresh water are lost through submarine springs downslope from Libya's Gebel al Akhdar range; the caves and karst of that range may be among the world's greatest. A recent attempted compendium of caves and karsts of Egypt and Libya contains several important errors; the supposed 5+ km Ain Zayanah Cave does not exist and the Zayanah System includes several smaller caves. The Bir al Ghanam gypsum karst of northwest Libya, however, has caves up to $3.5 \mathrm{~km}$ long. In Egypt, the Mokattam, South Galala, Ma'aza, Siwa and Western Desert karsts and the "White Desert" chalk karst of Farafra Depression are especially important. Qattara and nearby depressions may be karstic rather than structural in origin. Unique Wadi Sannur Cave is the world's largest gour and a potential World Heritage site. Little knownsandstone karsts or pseudokarsts in southwestern Egypt may contain analogues of features recently identified on Mars. The well-publicised Uweinat caves of northwestern Sudan are talus caves.
\end{abstract}

\section{Introduction}

With perhaps the single exception of gypsum karst in the far northwest corner of Libya (Kosa, 1981, 2001) caves and karsts in northeastern Africa have been virtually ignored until very recently. The speleological literature has contained little data on this area, and references to caves in the travel and archaeological literature have been scattered, non-descriptive geologically, and difficult to retrieve.

Much as in the case of comparable arid to hyperarid terranes in Saudi Arabia, however, this area suddenly has attracted considerable interest (e.g., Goodman et al, 1992; Gunay et al, 1997; Halliday, 2000, 2002); Laumanns, 2002; Pielsticker, 2002; Ruggieri, 2001; Waltham, 2001). As indicated below, an attempted 2002 literature integration contained serious errors. Another attempt (Halliday, Kosa, Pint and Salama-Mohamed, 2003) foundered with the subsequent 2003 death of Attila Kosa. Thus the present report should be considered merely a progress report on an area where much remains to be learned.

Not entirely by coincidence, this sudden flowering of desert speleology has paralleled

16530 Cornwall Court, Nashville, TN 37205 USA. 
a considerable expansion of hardy tourism in once-inaccessible parts of Egypt. Tour agencies compete on the web for travellers to Djara Cave (Garra Cave, Rohlf's Cave), not long ago considered one of the world's most inaccessible. Several attractive photos of its dripstone and a detailed 3-page description currently appear on the web.

Competition for tourists is even more intense at the long-remote Gilf Kebir plateau, a little-studied Mars-like sandstone karst or pseudokarst in the far Southwest corner of Egypt. A popular novel and movie entitled "The English Patient" featured the Cave of Swimmers and especially stimulated tourism here. It and other sandstone piping caves or rockshelters are repeatedly depicted on the web. Farther south, in northwestern Sudan, talus caves with notable pictographs also have become common tourist destination. Libya is a considerable contrast, but Italian speleologists have been seeking permission to build on 1970s studies by Yugoslavian, French and Hungarian hydrogeologists and speleologists discussed below.

\section{Karsts and karstic caves of Egypt and northern Libya}

At least potentially karstifiable rocks form the surface of much of Egypt and northern Libya but the percentage karstified is unclear. Their identification and study has been hindered by distances, regional aridity and lack of roads, by mantling by post-karstification marine transgressions, hard-packed gravel or wind-driven sand, and by language barriers (including indiscriminate application of the term "cave" in various languages to many mines, rockshelters and hewn tombs. Observation also is hindered by rapid surface disintegration of the characteristic carbonates: generally poorly consolidated, porous Cretaceous, Eocene and Miocene limestone in which intercalated marls and claystones serve as aquicludes.

Further, some of its karsts have unusual surface features which are not immediately recognisable as karstic (e.g., the "White Desert" chalk karst of Farafra Depression - Waltham, 2001). Others (e.g., parts of the Mokattam karst discussed below) are largely recognisable only by the presence of phreatic caves exposed in the vertical walls of small canyons termed wadis (Halliday, 2002a). Some others still are in the phreatic zone, without surface manifestations (Khalil et al, 2001). The karstic nature of the southern Galala Plateau (also discussed below) apparently was recognised only recently (Halliday, 2000) and some other karsts are named here for the first time.

Because karstic waters are very important to Egypt and Libya, some karstic hydrological studies here are more advanced than are traditional multidisciplinary studies. Especially in the Western Desert, these karstic waters characteristically arise from fissures in the underlying Nubian sandstone. Lesser quantities flow in fractured carbonates (Khalil et al, 1997; 2001). Much of this is fossil water and is not being recharged. In many karstic areas, the water table is dropping precipitously and seawater locally is migrating inland, with disastrous effects on agriculture. Remedial efforts seem to be of limited success to date. On the other hand, enormous quantities offresh groundwater are being lost to submarine springs in northeastern Libya (Kosa, 1986). 


\section{The Mokattam karst of northern Egypt}

The Mokattam karst is formed on a dissected limestone plateau on the eastern fringe of metropolitan Cairo. Here, typical karstic pollution and subsidence problems have necessitated broader studies than in most Egyptian karsts (e.g., El-Ramly, 1997). In addition, recent designation of the Wadi Degla Protected Area (the equivalent of a national monument in the USA) has focussed attention on small but remarkably varied caves of phreatic origin, which are the principal expressions of its karstification. One is a typical tubular conduit cave. Another descends steeply to a vertical shaft where initial reconnaissance had to be halted. This karst has been subjected to repeated marine transgressions since onset of speleogenesis (Fig. 1). A sequence of partially cemented stratified littoral fills is present in several of these caves (Halliday, 2000a) (Fig. 2).

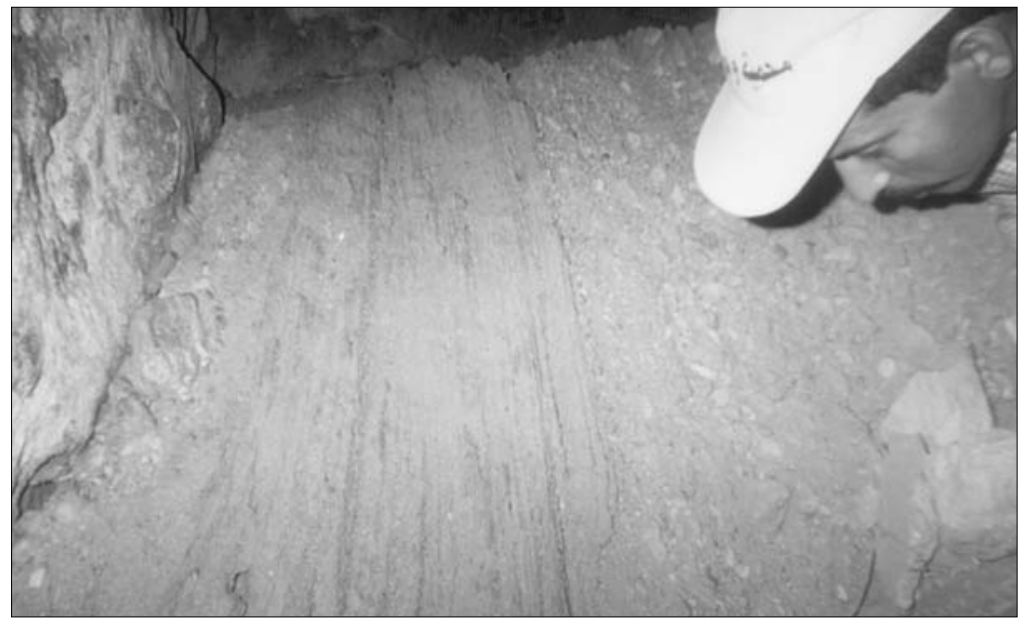

Fig. 1 -

Bat Cave,

Wadi

Degla

Protected

Area.

Stratified

cemented

fills from

post-karsti-

fication

marine

transgres-

sions

(Photo

W.R.H).

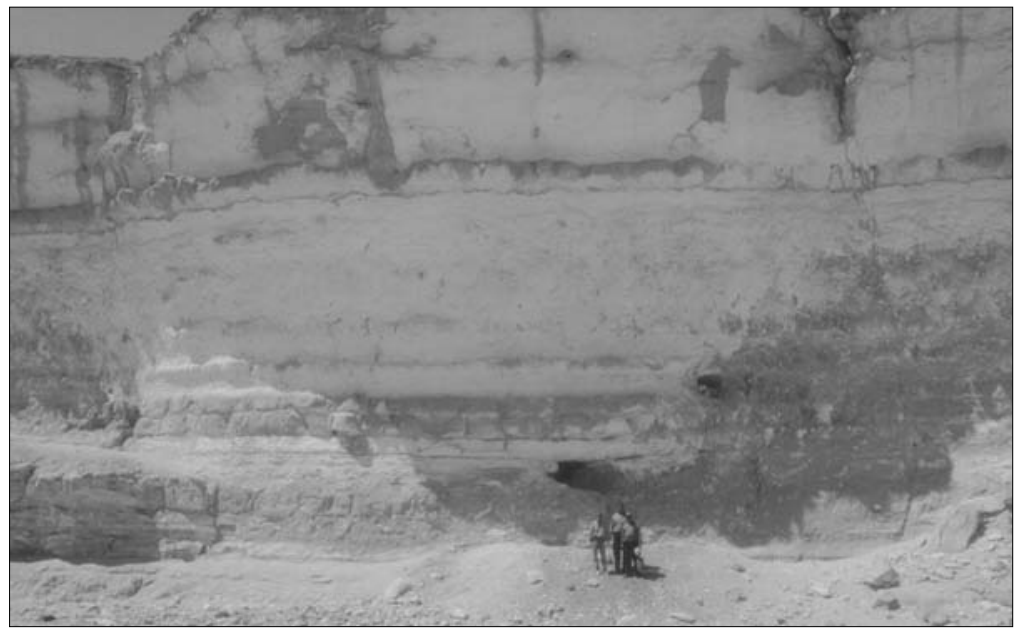

Fig. 2 -

Stratigraph ic section, Wadi Degla

Protected

Area. Two

entrances

of Beetle

Cave are

included.

(Photo

W.R.H). 
From the air, Wadi Degla is indistinguishable from many other wadis tributary to the northern Nile Valley. Alan Jeffreys has recorded some very small caves near Luxor (e.g., Jeffries, 1991) and similar karstic features may be surprisingly widespread in this area.

\section{Karst of the Southern Galala Plateau}

Several significant karstic features have been identified on the north end of the Southern Galala Plateau in the hyperarid Eastern Desert. Here, St. Anthony's Cave is very small but significant geologically as well as culturally (Halliday, 2000, 2001). It is a fossil resurgence cave in a comparatively dense Eocene limestone. The entrance is about $2.5 \mathrm{~m}$ high and $1 \mathrm{~m}$ wide (Fig. 3). A floor of nearly colorless flowstone - possibly Egyptian alabaster (see below) - extends outward as a shelf.

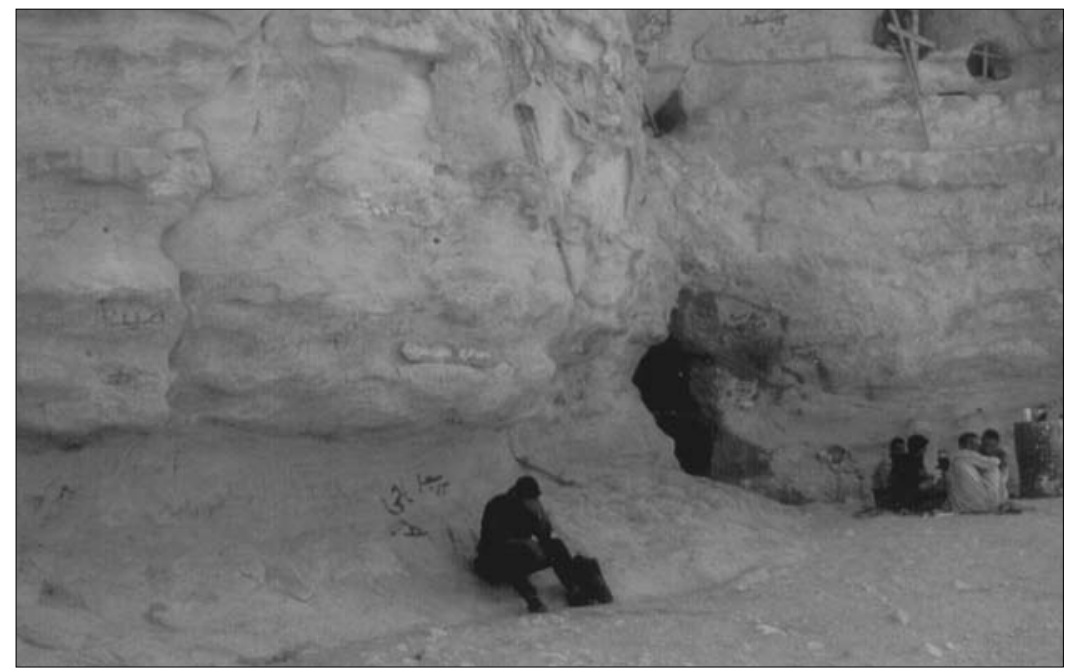

Fig. 3 - Entrance of St. Anthony's Cave and nearby karstic features. (Photo W.R.H).

Adjoining is a mass of similar material nearly $1 \mathrm{~m}$ in diameter, apparently filling a cavity of a fossil karst. Nearby are other small phreatic features. The entrance passage is phreatic and joint-controlled. About $0.5 \mathrm{~m}$ wide and $2 \mathrm{~m}$ high, it extends about $12 \mathrm{~m}$ to a drop-off of about $2 \mathrm{~m}$ into a small horizontal chamber inhabited by the saint from 312 to 356 A.D. This chamber is about $3 \mathrm{~m}$ wide and up to $3 \mathrm{~m}$ high. It was formed phreatically on a joint at 90 degrees to that of the entrance passage. Darkness is total in this room.

St. Anthony chose this site and the monastery was built here because of a karstic spring $275 \mathrm{~m}$ below the cave - the only water source in a very large area. Flowing from a narrow dissolution cave about $10 \mathrm{~m}$ long, it is said to yield about 100 cubic $\mathrm{m}$ per day and continues to supply the monastery village (Fig. 4). On the opposite (northeast) side of this plateau, one of the ancient buildings of St. Paul's Monastery is said to be partially built into a cave. 


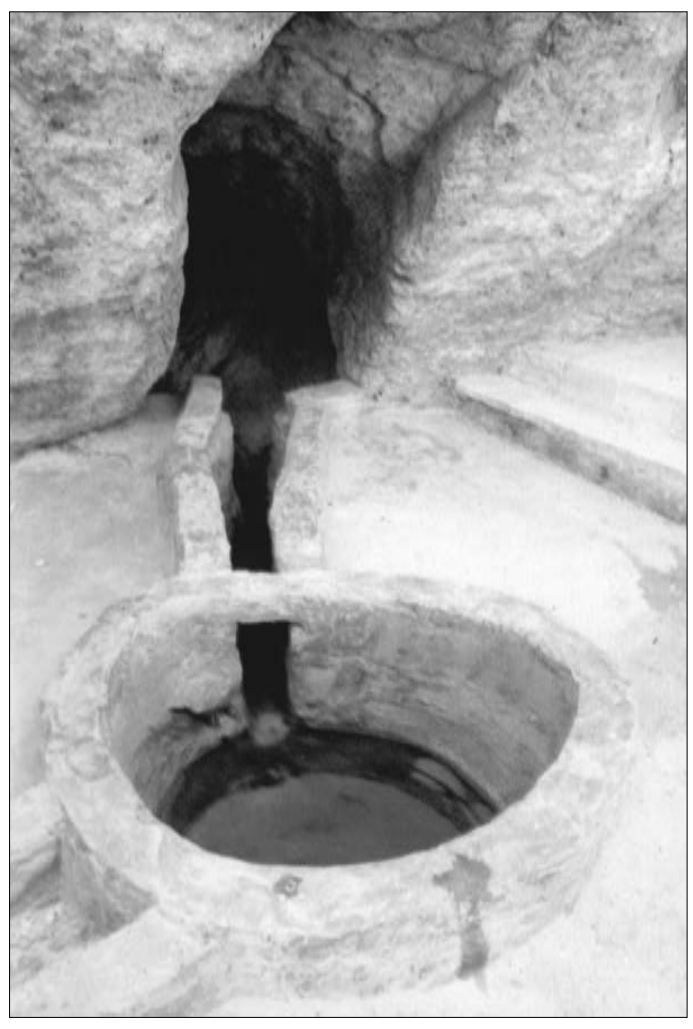

Fig. 4 - The water source of St. Anthony's Cave.

About $40 \mathrm{~km}$ southwest of St. Anthony's Cave, Nimir Cave is a sizeable solution cavern on the northern slope of the plateau. Its main chamber is $36 \mathrm{~m}$ long, $18 \mathrm{~m}$ wide and $11 \mathrm{~m}$ high. The vertical entrance is almost $3 \mathrm{~m}$ in diameter and drops $6.4 \mathrm{~m}$ to the floor. The floor consists of drifted sand and limestone talus. Amid the talus, a narrow multichamber labyrinth can be penetrated to a depth of about $10 \mathrm{~m}$. A large stalagmitic column dominates the far end of the main chamber. This cave is especially important for paleoecological studies, which revealed a "radically different" ecology

8880, and 3680 years B.P. (Goodman et al, 1992).

\section{Wadi Sannur Cavern}

Wadi Sannur Cavern is Egypt's most important and most beautiful cave. It is the principal feature of the Wadi Sannur Protected Area, located between Nimir Cave and the Nile River. It is in low rolling hills of disintegrating middle Eocene limestone and no relationship to the nearby southern Galala Plateau is evident. It is the world's largest gour and is a potential World Heritage Site (Halliday, 2002b, 2003).

The entrance of this world-class cavern is near the bottom of a pit-like quarry 50 $\mathrm{m}$ deep where Egyptian alabaster has been mined since Pharaonic days. This is one of many Egyptian calcareous thermal spring deposits of this ornamental stone. It has been called alabaster from very ancient times, long predating the application of this name to the calcium sulfate mineral also termed alabaster (Lucas, 1948). The cave was opened in 1991 by blasting and soon was found by a team of Egyptian geologists studying the quarry. Except for a few tiny vadose rivulet channels, it had been isolated from the surface for more than 40 million years. In this impoverished section of Egypt, economic pressures for quarrying away the cave were strong, but the Wadi Sannur Protected Area was created in 1998 and the Egyptian Environmental 
Affairs Agency has been entrusted with protecting the cave and opening it to the public. It was studied and mapped by a combined Turkish and Egyptian team of geologists in 1993. They presented their findings at an international symposium in southwestern Turkey in 1995 and their paper was published in its proceedings in 1997 (Günay et al, 1997).

Although nearly $50 \mathrm{~m}$ below the surface in nearly horizontal limestone, Wadi Sannur Cavern is not of solutional origin. Rather, it is constructional: a huge covered rimstone basin ("gour") $275 \mathrm{~m}$ long and up to $20 \mathrm{~m}$ high, curving more than halfway around the ancient thermal spring deposit. Very few other caves have been formed in this way; apparently Formation Cave, Idaho, USA is the only other example on record (Halliday, 1953), but has less than 1\% of the volume of Wadi Sannur Cavern. The latter is being readied for tourism by the Egyptian Environmental Affairs Agency. Because of the uniqueness, significance and beauty of the cave and the spring deposit, the complex is a serious candidate for World Heritage Site status.

Basically, the cave is an impressive flat-floored curving chamber, crescentic in floor plan. Massive speleothems and curving walls partially demarcate eastern and western galleries. Both ends taper and slope slightly upward. The inner wall of the crescent is almost vertical. The cave's roof is almost horizontal at the inner wall, then curves downward to meet the floor as much as $12 \mathrm{~m}$ away. Except at each end, the floor consists of dried, layered mud up to $1 \mathrm{~m}$ thick, with a cracked surface of recent origin.

Along the outer wall at the apex of the curve are several small shafts, which permit upward inflow and subsequent drainage of floodwaters. The depth from the cave to the water table is unknown, but evidence of repeated flooding with torrential desert rainfalls suggests that it is comparatively close.

Because it is one of only two caves in the Eastern Desert currently known to have speleothems suitable for isotopic dating, Wadi Sannur Cavern has received considerable scientific attention. Results consistent with deposition in early to middle Holocene time (Railsback et al, 2002) followed a preliminary study which showed considerable scatter (Dabous and Osmond, 2000). Some speleothems, however, have a very fresh, glistening appearance and may have been deposited or enlarged very recently, during periods of partial flooding (Fig. 5). Such speleothems are the cave's great glory, and were the first features recognized as worthy of protection. They range from towering stalactitic columns and subaqueous mammillaries to glistening thickets of intricate crystalline "popcorn" and tiny glassy helictites (Fig. 6). Stalactites vary from soda-straw forms to large tapered types. Some have secondary coatings of various thickness. Others are so glassy that they appear monocrystalline. At first glance, their presence beneath a barren, hyperarid surface must have appeared miraculous. In reality, they demonstrate that subsurface karstic features may appear in locations far removed from surface evidence of speleogenesis. No surface evidence of karstification is evident here, but the walls of the quarry and adjoining roadcut contain numerous small phreatic cavities. Some enclose terra rossa and/or small speleothems. Diagenesis is locally prominent. A few km distant, karren are present on a low cliff. 


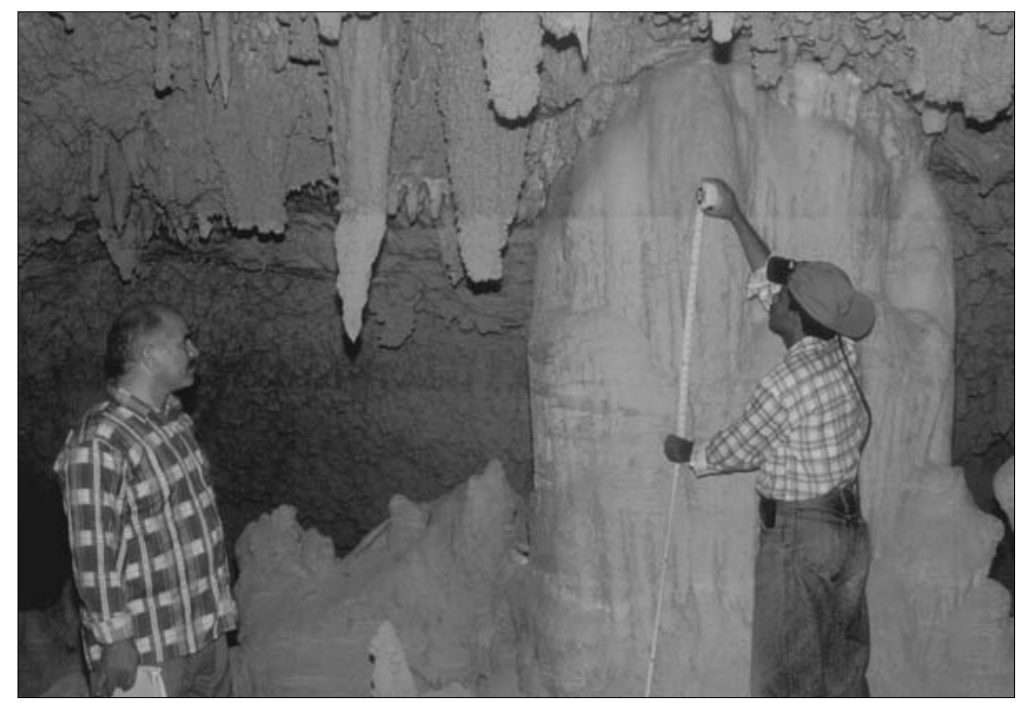

Fig. 5 - Flood lines in Wadi Sannur Cavern. (Photo W.R.H).

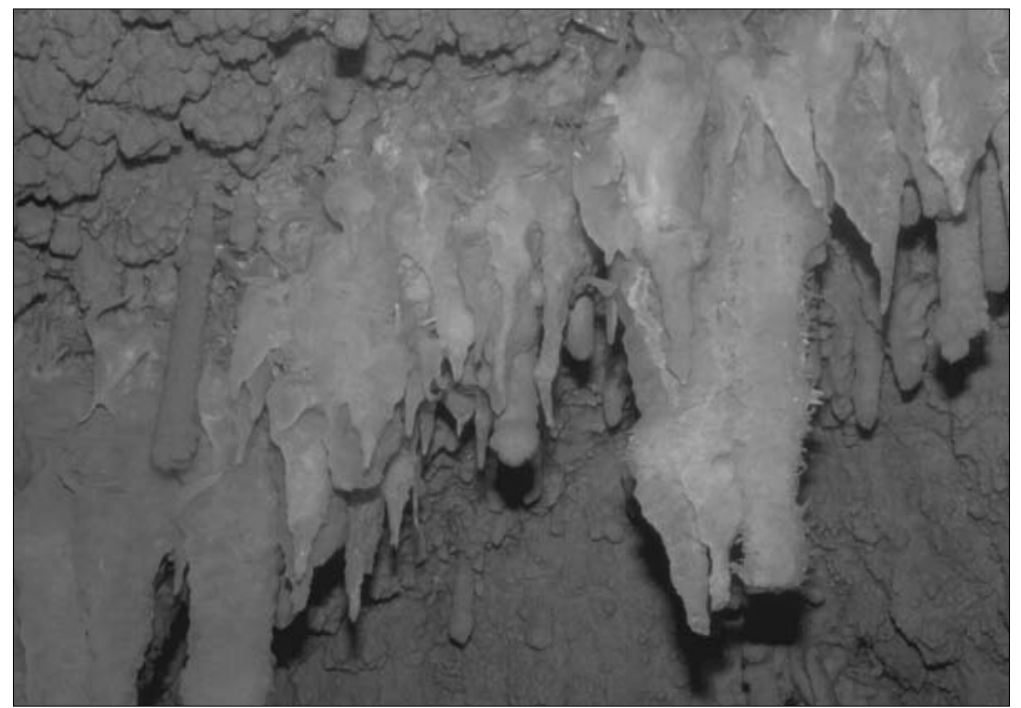

Fig. 6 - Complex speleothems in Wadi Sannur Cavern. (Photo W.R.H).

\section{Ma'aza karst}

Farther south in the Eastern Desert, Hume (1925) reported caves in Wadi Um Dud east of Taha, and depicted the location of "Big Cave", "Great Cavern" and unnamed caves in Wadi Gasab and Wadi Abu Nefukh farther south. Others were said to be east of nearby Wadi Qena, where "honeycombed" limestone also is said to be present. No speleologist is known to have investigated this area. 


\section{Western Desert karsts}

The Western Desert contains a large limestone plateau, which extends north south, west of the Nile Valley. It largely consists of almost horizontal Cretaceous chalk and Eocene limestone. In it are two large depressions, which contain the Bahariya and Farafra oases. Both were formed on breached anticlines. These and nearby Dakhla and Kharga oases (below the western rim of the plateau) receive small flows from perched aquifers but more of their water supply rises along faults from the underlying Nubian sandstone: a truly great aquifer. The most famous karstic features of the plateau are extraordinary chalk pillars, towers and rounded blocks in the "White Desert" chalk karst of Farafra Depression (Waltham, 2001). But many other surface and subsurface features are present.

The most important cave currently known on this plateau is Djara Cave (Garra Cave, Rohlf's Cave) located in hyperarid terrain between Assyut and Farafra Oasis. Recently it has become a tourist attraction and has been described on the Internet, depicted by Ruggieri (2001), and studied by Brook at al (2002). It is a dissolution cave, consisting mostly of a single spacious chamber about $40 \mathrm{~m}$ long, with considerable dripstone and wind-blown sand. Of the speleothems studied by Brook et al (2002), none were deposited in Holocene time. In its pattern, locale and speleothems, it resembles several Saudi caves reported (via the Internet) by John Pint of the Saudi Geological Survey.

Also in the Farafra area is the Wadi al-Obayyid archaeological cave and perhaps another by the same name. El-Sayed (1995) mentioned additional small karstic features including sinkholes and caves with dripstone up to $0.8 \mathrm{~m}$ long. It is not clear whether any of these are in the "Crystal Mountain" karstic area increasingly publicised as a tourist area or in the Naqb ElSalim or Naqb ElSalim-Farafra depressions said to have especially prominent speleogenesis.

Near the road from Farafra to Bahariya oasis are extensive exposures of Egyptian alabaster, which have the general form of flowstone. Pielsticker (2002) has attributed their presence to unroofing of a large cave. They appear to generally resemble travertine features of the famous white terraces of Turkey's famous Pamukkale thermal spring, but Pielsticker reported a covered space $30 \mathrm{~m}$ long.

On the eastern flank of the plateau, small caves are reported along the road from Edfu to Dush in the Kharga oasis and in Wadi Karnak (Ruggieri, 2001), and a karstic spring is present about halfway up the cliff north of Dush (Ball, 1900). Other karstic springs are present at the flatlands at its base. Large closed depressions are seen on maps of the nearby plateau surface. The " 150 caves" supposedly on Gebel al Tarif near Nag Hammadi on the Nile River, however, probably are rock-hewn tombs.

\section{Siwa karst or karsts}

In the limestone plateau south of the famous World War II battlefields of El Alamein and Mersa Matruh are Siwa oasis, world-famous Qattara Depression and many other closed depressions, large and small. These are generally classified as 
structural depressions, but on various maps (e.g., 1986 1:100,000 Al Alamayn Quadrangle and 1956 AMS 1:100,000 El Alamein Quadrangle), their patterns are so varied and so complex as to suggest a karstic origin. Siwa oasis has been impacted by overpumping of karstic ground water and a separate natural salt water reservoir is present at depth (Khalil et al, 2001). In this general area, caves have been reported on Gebel al-Mawta, Gebel Tunefafan and Quasr Hassuna but it is not clear that any of these are natural features.

\section{Mediterranean littoral karsts}

Along the Mediterranean coast westward from Alexandria to and beyond Mersa Matruh, numerous karstifiable aeolianite dunes are superimposed on limestone and gypsum formations. Many caves are shown on topographic maps of this strip (e.g., 1951 AMS 1:100,000 Borg Al-Arab Quadrangle) but it is unclear how many of these are rock-hewn tombs or other excavations. It is not even clear that historic Rommel's Cave just east of Mersa Matruh is a natural feature.

\section{Caves and karsts on the Sinai Peninsula and Red Sea Ranges}

Numerous maps of the Sinai Peninsula show two identical spelean place names: Gebel Magara (Cave Mountain). These are ancient turquoise mines. Eocene limestones on the Gebel um Ksheib massif "have a tendency to the formation of large caves" (Moon and Sadek, 1921, p. 92.) "Hot Caves" apparently in limestone near sea level at the north end of Hamman Faraun Range are described as narrow clefts, which widen to inner chambers where the air temperature exceeds 38 degrees Celsius. Sizeable gypsum bubble caves exist farther north (Moon and Sadek, 1923). Several sandstone rockshelters on the Sinai Peninsula are tourist attractions, used for overnight stays. So-called caves in the vicinity of St. Catherine's Monastery (e.g., Elijah's Cave on Mt. Horeb and another atop Mount Sinai (Gebel Musa) are granitic rockshelters. Newspaper accounts have announced archaeological finds in large caves far to the south, on the western side of the Red Sea in geologically complex mountains.

\section{Possible pseudokarsts of Egypt}

Cave of Swimmers is the most publicised of several known caves or rockshelters in the hyperarid Gilf Kebir, a dissected sandstone plateau of far Southwest Egypt. If these are piping caves, they are of special interest as potential analogues of cavernous features on Mars (e.g., El-Baz and Maxwell, 1982). To date, most have been studied only by archaeologists and it is not clear whether they are karstic or pseudokarstic, or are best classified in a semantic interface between them. Surprising vegetated areas recently found in this supremely hyperarid area apparently have not been visited by hydrogeologists. Fluid basalt flows capable of forming lava tubes may exist on at least one volcanic island in the Red Sea. 


\section{Caves and karsts of Libya}

Ghoudarsi (1970) contains a notable overview of karstifiable rocks in Libya. Speleologically and historically, this country consists of Tripolitania (NW Libya) and Cyrenaica (NE Libya). The karstic features of both are incompletely known and considerable confusion has resulted from a recent attempt to correlate data produced by various 20th Century sources in various languages. Attila Kosa (e-mail communications, 2003) considered Laumann's 2002 "Karst Location Map" to be misleading, with errors of fact in the accompanying text (Laumann. 2002).

In Tripolitania, the only well-studied karst is found in the Bir Al Ghanam gypsum formation southwest of Tripoli (Kosa, 1981, 2001). Currently the longest cave in Libya is its Umm al Masabih, with $3.593 \mathrm{~km}$ surveyed. Also present are three significant systems in the Abu an Niran area, 0.5 to $1.0 \mathrm{~km}$ long. Each of these consists of three physically separate segments. The Ain Wadi Fasat system also has three separate segments, with a total of at least 600 meters of passage; further exploration appears feasible. Other gypsum outcrops in Tripolitania also appear karstified.

No caves have been found in dolomitic limestone in far Northwest Tripolitania, but a considerable potential exists in broad upper Triassic (?) limestone plateau some $250 \mathrm{~km}$ south of its coast. The sole karstic feature currently on record here, however, is an impressive "pothole" with overhanging walls, widening from a $26 \mathrm{~m}$ vertical entrance to a maximum width of $85 \mathrm{~m}$. 86 meters below the surface is a freshwater lake of uncertain depth, heavily polluted by pigeons (Kosa, 1981, 2001). This "pothole" and similar features in Cyrenaica (see below) more closely resemble the Devil's Sinkhole of western Texas, USA and perhaps the sotano-like pit caves of the Arabian Peninsula than any feature known on the limestone plateaus of Egypt. Kosa found other, smaller pit caves on the Tripolitanian limestone plateaus but could not investigate them because of remoteness, lack of backup personnel, and notably friable limestone surfaces.

\section{Caves and Karst of Cyrenaica}

In addition to pit caves of the limestone plateaus of Cyrenaica (see below), Cyrenaica is notable for the features of its Jabal al Akhdar karsts. This well-watered group of karsts extends eastward from the city of Benghazi toward the Egyptian border. It includes a wide range of topography, from littoral mixing zone karsts and submarine springs to mountains, which rise to an altitude of about 800 meters. Faulting has produced three levels of surface exposures of karstifiable Miocene limestone, seemingly much like the coastal range of Lebanon on a smaller scale. In contrast to the great freshwater resurgence of Lebanon's Jeita Cave, however, the lowest level of the karst is largely within and beneath the current littoral mixing zone.

Superficial karstic features in and around Benghazi have attracted since Greek and Roman times. In a restricted military base in central Benghazi, Lethe Cave is a large chamber with a brackish lake. It is supposed to be the Lethe or River of Forgetfulness of ancient legendary. A somewhat similar cave in the suburbs also claims this hon- 
our; it appears that Preble (1945) went to the latter by mistake (A. Kosa, e-mail communication, 2003). Nearby is Rommel's Pool, a large sinkhole flooded by brackish water and perhaps other water table features.

In the 1970s, the Ayn Zayanah karst (a few km farther north of Benghazi) was studied by Jugoslavian, then by French hydrogeologists. Their reports to the Libyan Government are not widely available but were summarised by Kosa who also was working for the Libyan General Water Authority in the 1970s. In a paper presented at the $7^{\text {th }}$ International Congress of Speleology he included the map of the Ayn Zayanah System produced by the Societé des Eaux de Marseille (Kosa, 1977). In contrast to his fieldwork in other parts of Libya, Kosa here did only surface reconnaissance (A. Kosa, e-mail communications, 2003). His visit to Zayanah Spring has been misinterpreted; he did not find an underwater cave entrance at the spring, much less an orifice of a supposed 5+ km Zayanah Cave as cited by Laumanns (2002). Although the Al Zayanah System currently contains about $4.8 \mathrm{~km}$ of passages Kosa (1977) clearly showed that no single cave of such magnitude was found. Instead, there are several individual caves linked by dye traces: Al Merisi Cave $(2.117 \mathrm{~km})$, Al Habibi-Bukarma Cave (1.5 km), Jumar Pit, and several other caves less than $1 \mathrm{~km}$ in length. The majority of the system is completely flooded, with its maximum depth in excess of $80 \mathrm{~m}$. Especially at its down-slope end, additional discovery appears likely. The system appears fascinatingly similar to mixing-zone caves in the Florida littoral containing independent streams in a branchwork pattern, but is larger and deeper. Its waters are too brackish for domestic use, but farther Northeast in the littoral, enormous quantities of fresh groundwater are lost through submarine karstic springs (Kosa, 1977).

Elsewhere in Cyrenaica, the famous Cave of Apollo in the ruins of the ancient Greek city of Cyrene (now Al Shahhat) is a unitary resurgence conduit about $300 \mathrm{~m}$ long. Sorgente de Massah is similar and about $450 \mathrm{~m}$ long. (Laumanns, 2002). Contrary to Laumanns (2002). Abraq Cave was not found to reach the water table, however. (A. Kosa, e-mail communication, 2003). Its pattern is a type common in Saudi Arabia.

Several karstic pits more than $50 \mathrm{~m}$ deep are on record in Cyrenaica. Near Cyrene, Hawa Balkhtak apparently is much like Tripolitania's Ain Misraq, on a grander scale. The apparent bottom of Muntaqa Aqaranta was barely visible when its explorers reached the end of their 100 metres rope (A. Kosa, e-mail communication, 2003). This part of Cyrenaica may be found to be one of the world's truly great karst areas.

Evaporite karsts also are present in Cyrenaica but have not ben studied. Sandstone "niches" in hyperarid southern Libya may be in sandstone karsts or pseudokarsts (A. Kosa, e-mail communications, 2003). If so, these may have potential similar to or greater than those of Egypt's Gilf Kebir.

\section{Caves and Karsts in northern Sudan}

No significant karsts are known in northern Sudan. In the far Northwest desert, in the Gebel Uweinat south of Egypt's Gilf Kebir plateau, visitors to famous caves of 
archaeological and historical interest have described them in various ways. The report by Cox (1934) that they are talus ("boulder") caves is especially convincing.

\section{Conclusions}

Recent investigations have demonstrated notable potential for karst studies in many parts of Egypt and northern Libya. Libya's Jabal al Akhdar and plateaus to the south may be one of the world's greatest karstic areas. It should undergo intensive investigation when the political situation stabilises in Libya. Access to karsts in Egypt's Western Desert has improved greatly in recent years. Its Ma'aza Plateau is even less known karstically. The 1978 NASA expedition to the Gilf Kebir sandstone plateau did not investigate possible piping analogues to Martian features and extensive investigations are warranted here also.

\section{REFERENCES}

BALL J., 1900 - Kharga Oasis: Topography and Geology. Survey Dept., Public Works Ministry, Geological Survey (of Egypt) Report for 1899, Part II, Cairo, Natl. Printing Dept.

BROOK G., EMBABI N., EDWARDS R., COWART J. \& DABOUS A., 2002 - Djara Cave in the Western Desert of Egypt: Morphology and Evidence of Quaternary Climatic Change. Cave and Karst Science, 29 (2): 57-65.

COURBON P., CHABERT C., BOSTED P. \& LINDSLEY K.,1989 - Atlas of Great Caves of the World. St. Louis. Cave Books.

COX P., 1934 - Introduction. In: PENDEREL H.W.G.J., 1934 - The Gilf Kebir. Geographical Journal, 83 (6): 450. Reproduced in:

http//www.sff.net/people/scsmith/ep/article1.html.

DABOUS A. \& OSMOND J., 2000 - U/Th isotopic study of speleothem from the Wadi Sannur Cavern, Eastern Desert of Egypt. Carbonates and Evaporites. 15 (1): 1-6.

EL AREF M., KHADRAM A. \& LOFTY Z., 1987 - Karst Topography and Karstification Processes in the Eocene Limestone Plateau of El Bahariya Oasis, Western Desert, Egypt. Zeitschr. für Geomorph., N.F., 31 (1): 45-64.

EL-BAZ F. \& MAXWELL T.A. (Eds.), 1982 - Desert Landforms of Southwestern Egypt: a basis for comparison with Mars. NASA CR-3611: 1-372.

EL-RAMLY I., 1997 - El Mokattam City: karst problems. In: GÜNAY G. \& JOHNSON A. (Eds.) - Karst Waters and Environmental Impacts. Proc. 1995 Symp. On Karst Waters and Environmental Problems, Antalya, Turkey, 10-20 Sept. 1995. A.A. Balkema, Rotterdam: 85-92.

EL-SAYED M., 1995 - Duricrust and karst pinnacles in and around Farafra Oasis, Western Desert, Egypt. Sedimentology of Egypt, 3: 27-38. 
GOODMAN S., HOBBS J. \& BREWER D., 1992 - Nimir Cave: morphology and fauna of a cave in the Egyptian Eastern Desert. Paleoecology of Africa, 23: 73-90

GÜNAY G. \& JOHNSON A. (Eds.) - Karst Waters and Environmental Impacts. Proc. 1995 Symp. On Karst Waters and Environmental Problems, Antalya, Turkey, 10-20 Sept. 1995. A.A. Balkema, Rotterdam.

GÜNAY G., EKMEKCI M., BAYAN C., KURTTAS T. \& EL-BEDEWY, 1997 - Sannur Cave: a crescent shaped cave in Egypt. . In: GÜNAY G. \& JOHNSON A. (Eds.) - Karst Waters and Environmental Impacts. Proc. 1995 Symp. On Karst Waters and Environmental Problems, Antalya, Turkey, 10-20 Sept. 1995. A.A. Balkema, Rotterdam: 257-262.

HALLDAY W., 1953 - An unusual cave in travertine. Cascade Cave Report, 6: 4-6.

HALLIDAY W., 2000 - St. Anthony's Cave, Eastern Desert of Egypt. 2000 Speleodigest, Natl. Spel. Soc., Huntsville, AL, USA, (Reprinted from Speleograph) 302: 320.

HALLIDAY W., 2001 - Karst at Saint Anthony's Monastery, Eastern Desert of Egypt (abstract). Proc. Symp. Middle-East Speleology 2001. Kaslik (Lebanon), 20-22 April 2001. Beirut, Speleo-Club du Liban: 120.

HALliDAY W., 2002a - Caves of the Wadi Degla Protected Area: initial reconnaissance April 27, 28 and 30, 2001. Report prepared for the Egyptian Environmental Affairs Agency: 1-19.

HALLIDAY W., 2002b - Protection of Wadi Sannur Cavern. Report prepared for the Egyptian Environmental Affairs Agency: 1-15.

HALLIDAY W., 2003 - The world's largest gour: Wadi Sannur Cavern, Egypt. NSS News, 61 (1): 4-6.

HALLIDAY W., KOSAA., PINT J. \& SALAMA-MOHAMED A., 2003 - Karst in the Desert: Karsts and Caves of Egypt, Northern Libya and Saudi Arabia (abstract). Proc. Karst Waters Inst. Int. Conf. on Karst Hydrogeology and Ecosystems, Karst Waters Inst., Bowling Green, KY, June 3-6, 2003: 29-30.

HUME W., 1925 - Geology of Egypt. Government Press, Cairo, 1: 91, 141 and Plates XLI and LI.

JEFFREYS A., 1991 - Kahf al Sahm al Asrek: a Small Cave in Egypt. Bull. Grampian Speleol. Group, 2(2): 16-17.

KHALIL J., EL-HOSSARY M. \& FIRKY A., 2002 - Speleology of Carbonate Aquifer System in Siwa Oasis, Egypt. Proc. Symp. Middle-East Speleology 2001. Kaslik (Lebanon), 2022 April 5001. Beirut, Speleo-Club du Liban: 130-133.

KHALIL J. \& HASSAN T., 1997 - Hydrogeological aspects of karstified aquifer and its environmental impacts in Eastern Desert, Egypt. In: GÜNAY G. \& JOHNSON A. (Eds.) Karst Waters and Environmental Impacts. Proc. 1995 Symp. On Karst Waters and Environmental Problems, Antalya, Turkey, 10-20 Sept. 1995. A.A. Balkema, Rotterdam.

KOSA A., 1977 - Hydrological Problems in the Ayn Zayanah Karst System, Benghazi, Libya. Proc. $7^{\text {th }}$ Int. Speleol. Congr., Sheffield, England: 275-277. 
KOSA A., 1981 - Bir al Ghanam Karst Study Project, Final Report. NIKEX-OVIBER Drilling Company, for the Secretariat of Agricultural Reclamation and Land Development, Tripoli, Libya, $2^{\text {nd }}$ Edition, 2001. CD-ROM, Published by the Author, Budapest.

KOSA A., 1986 - Karst water resources development in Africa. Africana, Budapest, 2: 67-69.

LUCAS A., 1948 - Ancient Egyptian Materials and Industries. Edwards Arnold \& Co., London, $3^{\text {rd }}$ Ed:: 1-75.

MOON F. \& SADEK H., 1921 - Topography and Geology of Northern Sinai, Part I - Session 1919-1920. Ministry of Finance (Egypt), Petroleum Research Bulletin No. 10, Cairo, Government Press.

MOON F. \& SADEK H., 1923 Preliminary Geological Report on Wadi Gharandel Area. Ministry of Finance (Egypt), Petroleum Research Bulletin No. 10, Cairo, Government Press.

PIELSTICKER K.-H., 2002 - Tropfsteine in der Ägyptischen Sahara (vorlaufiger Bericht). Mitt. dt. Höhlen- und Karstforsch.. 48 (4): 98-102.

PREBLE J., 1945 - Caves of the River Styx. Bull. Natl. Spel. Soc., 7: 13-15.

RAILSBACK L., DABOUS A.A., OSMOND J.K. \& FLEISHER C.J., 2002 - Petrographic and geochemical screening of speleothems for $U$-series dating: an example from recrystallized speleothems from Wadi Sannur Cavern, Egypt. J. Cave and Karst Studies, 64 ( 2): 108-116.

RUGGIERI R., 2001 - Speleologia d'Egitto. Speleologia, Soc. Spel. Italiana, Bologna, 45: 4251.

WALTHAM T., 2001 - Pinnacles and barchans in the Egyptian Desert. Geology Today, 17 (3): 101-104.

ZITTEL K., 1883 - Beträge zur Geologie und Paläontologie in der Libyschen Wüste. Paleontographica, XXX: 141.

Received: 3 november 2003

Accepted: 12 december 2003 